\title{
ESL Teachers' Experience in Teaching Pupils with Dyslexia in Mainstream Classrooms
}

\author{
Suhana Ahmad1, Manisah Mohd Ali', Khazriyati Salehuddin² \\ ${ }^{1}$ Faculty of Education, Universiti Kebangsaan Malaysia, Bangi, Malaysia \\ ${ }^{2}$ Faculty of Social Science and Humanities, Universiti Kebangsaan Malaysia, Bangi, Malaysia \\ Email: suhana388@gmail.com,mma@ukm.edu.my, khazudin@ukm.edu.my
}

How to cite this paper: Ahmad, S., Ali, M. M., \& Salehuddin, K. (2018). ESL Teachers' Experience in Teaching Pupils with Dyslexia in Mainstream Classrooms. Creative Education, 9, 2171-2182. https://doi.org/10.4236/ce.2018.914158

Received: August 16, 2018

Accepted: October 26, 2018

Published: October 29, 2018

Copyright ( 92018 by authors and Scientific Research Publishing Inc. This work is licensed under the Creative Commons Attribution International License (CC BY 4.0).

http://creativecommons.org/licenses/by/4.0/

(c) (i) Open Access

\begin{abstract}
In Malaysia, pupils with dyslexia mostly learn English as a second language (ESL) in mainstream classrooms together with other children. It is known that language learning is the biggest struggle for pupils with dyslexia and learning ESL is even more challenging for them. This paper aims to explore three ESL primary school teachers' experiences in teaching pupils with dyslexia, particularly the challenges they encounter as well as the strategies they use to assist them in the teaching and learning process. In-depth interviews were conducted with the teachers for the data collection. The findings show that those ESL teachers find it challenging to teach pupils with dyslexia and they are lacking effective teaching methods to apply in the classroom to support the students. Several recounts of teaching experiences show that ESL teachers need more support in terms of training and professional development to ensure literacy skills mastery among pupils with dyslexia.
\end{abstract}

\section{Keywords}

Dyslexia, English as a Second Language, Teacher's Experience, Teaching

Challenges, Teaching Strategies

\section{Introduction}

Individuals who do not master a second or foreign language in today's world are not competitive enough in the job market and this may even affect their personal life. Learning English as a second (henceforth, ESL) or as an additional language elevates an individual's value within his/her society not only because English is a prestigious language but also because English is one of the most used language in the world. Every child should not be deprived from learning English since it could bring them further in terms of education attainment and career fulfill- 
ment. Unfortunately, some children experience specific learning difficulties in relation to language learning such as dyslexia. This condition makes it harder for them to learn and master a second or an additional language. Most language teachers have problems to fulfill the special needs of these pupils due to some reasons such as the lack of knowledge related to the pupils' special needs, their ignorance of affective and cognitive strategies used by the pupils, and the fact that they are unequipped with suitable language teaching tools (Kormos, Csizér, \& Sarkadi, 2009). Although it is essential to examine the process of language acquisition for pupils with special needs, there are still very few studies focusing on pupils with dyslexia. Previous recent studies in this area have focused on teachers' understanding and awareness of dyslexia (Worthy, Dejulio, Svrcek, Villarreal et al., 2016) and quantitative in nature (Bell, Mcphillips, \& Doveston, 2011).

Although it is important to focus on the needs of pupils with dyslexia in learning a language, understanding the experiences of ESL teachers in dealing with pupils with dyslexia in the mainstream settings is also relevant. The perspectives and experiences of these ESL teachers can help school administrators, teachers and parents understand the kind of teaching experiences that are needed to teach ESL to pupils with dyslexia and the kind of needs and supports that ELS teachers wish to be provided. ESL teachers of pupils with dyslexia in Malaysia make an interesting case study as these teachers are those who teach pupils from various ethnic backgrounds, mainly Malay, Chinese and Indians, whose first language is totally different from English language. Hence, the aim of this study is to provide an in-depth account of ESL teaching experience of Malaysian pupils with dyslexia. For this purpose, interviews were conducted on three ESL teachers who teach pupils with dyslexia in mainstream settings from three different primary schools in Peninsular Malaysia.

\section{Understanding Dyslexia in ESL Context}

Dyslexia is a specific learning disability that impacts reading spelling and writing. The International Dyslexia Association has a more thorough definition for the term dyslexia as below:

"Dyslexia is a specific learning disability that is neurobiological in origin. It is characterized by difficulties with accurate and/ or fluent word recognition and by poor spelling and decoding abilities. These difficulties typically result from a deficit in the phonological component of language that is often unexpected in relation to other cognitive abilities and the provision of effective classroom instruction. Secondary consequences may include problems in reading comprehension and reduced reading experience that can impede growth of vocabulary and background knowledge." (International Dyslexia Association, 2002).

It is clear that this definition emphasizes on the brain functions as the cause of the difficulties in learning to read, spell and write faced by individuals with dyslexia, besides mentioning several effects of this condition such as impaired com- 
prehension and the loss of vocabulary and reduced general knowledge.

Such effects of problems in reading, spelling and writing definitely lead to problems in learning English as a second language (ESL) among pupils with dyslexia. English language has deep orthography (Sotiropoulos \& Hanley, 2017), meaning the grapheme-phoneme correspondence is not as transparent as some languages like Malay (Lee, 2008), Spanish or German. For most Malay children with dyslexia whose Malay language is their mother tongue, learning ESL could be intimidating even though both Malay and English language have alphabetic orthographic.

In the Malaysian education system, dyslexia is categorized as one type of learning disability and pupils with dyslexia can be placed in three types of placing: full inclusion, partial inclusion, or integration setting (Special Education Integration Program-SEIP). The Special Education Department under the Ministry of Education defines pupils with dyslexia as "pupils who have average or higher than average intelligence but having difficulties or severe weakness in reading, spelling and writing skills" (Instrumen senarai semak disleksia BM, 2014).

Many studies on teaching ESL/EFL/EAL to pupils with dyslexia have been conducted around the world such as in Poland (Lockiewicz \& Jaskulska, 2016), China (Kalindi, McBride, Tong, Wong, Chung, \& Lee, 2015), United Kingdom (Reraki, 2014), Spain (Bellocchi, Tobia, \& Bonifacci, 2017), and Nigeria (Ogunsola, 2018). These studies examined various aspect of English language teaching such as reading accuracy and fluency (Lockiewicz \& Jaskulska, 2016; Kalindi, McBride, Tong, Wong, Chung, \& Lee, 2015), reading comprehension (Bellocchi, Tobia, \& Bonifacci, 2017; Farukh \& Vulchanova, 2016) and vocabulary knowledge (Duff, Hulme, Grainger, Hardwick, Miles, \& Snowling, 2014).

In Malaysia, however, the studies conducted have always been based on the Malay language. Some of them were on teaching pupils with dyslexia focusing on the use of multisensory techniques in teaching Malay language (Subramaniam \& Che Mat, 2013); identifying dyslexia problems among remedial pupils (Ramasamy, 2008); and developing and validating a reading test in Malay language to identify dyslexia (Lee, Ali, \& Salleh, 2008). Very little studies focus on the aspect of teaching ESL to pupils with dyslexia (Balakrishnan, Chong, Idris, Othman, Wong, Nor, \& Azman, 2015). Besides, Malaysian ESL teachers' perspectives have not yet been explored when this information could greatly contribute to improved ESL teaching and learning strategies for pupils with dyslexia.

This study employs a case study design to explore the experiences of ESL teachers who teach pupils with dyslexia in primary schools in Malaysia. The research presented in this paper seeks to answer the following questions:

1) What are ESL teachers' experiences in teaching pupils with dyslexia in mainstream settings?

2) What are the challenges faced by ESL teachers in teaching pupils with dyslexia in mainstream settings?

3) What are the strategies used by ESL teachers in teaching pupils with dyslexia in mainstream settings? 


\section{Methodology}

This study is qualitative in nature and therefore, it employed semi-structured interview which involved 3 participants which were selected through purposive sampling technique. Although the number of participants in this study is very small, it is essential to explore personal experience of the teachers in order to inform on the current practise and situation in primary school setting. From the list of 44 primary schools with SEIP Dyslexia Program, three schools which provide the ESL teaching and learning for pupils with dyslexia in mainstream classrooms, alongside with other typically developing pupils, were chosen. This was done because there are some primary schools that conducted their ESL classes for pupils with dyslexia in a special setting where the teacher focuses on teaching a small group of pupils or have a one-to-one instruction with their student. The focus of this study is on the experiences of ESL teachers who deal with pupils with dyslexia in the mainstream classrooms since this takes place in most schools nationwide. ESL teachers from the selected schools were contacted and asked on their willingness to participate in this study. The ESL teachers must fulfil several criteria; they must be ESLoptionist teachers, have at least three years' experience in teaching pupils with dyslexia, and teach pupils with dyslexia in mainstream classrooms. Table 1 below shows the characteristics of the participants:

The interview guide used in this study was developed based on the basis of the relevant literature concerning the experiences, the challenges, and the strategies of language teachers who teach pupils with dyslexia (Subramaniam \& Che Mat, 2013; Liyana, Hanapi, Zakaria et al., 2013; Pin, 2013). It consists of ten guiding questions. The interviews were conducted in both English and Malay language according to the preference of the participants. Pseudonyms such as Teacher A, Teacher $\mathrm{B}$ and Teacher $\mathrm{C}$ were used to ensure anonymity and secure their identities. Each interview lasted for approximately 45 minutes. The interviews were recorded and transcribed verbatim by one of the authors. The responses elicited from the participants were analyzed thematically in order to find the answers to the research questions of this study.

\section{Findings and Discussion}

This section will discuss the findings from the interviews in exploring the ESL teachers' experience, challenges and strategies in teaching English language to pupils with dyslexia in mainstream classrooms.

Table 1. The overview of the participants' characteristics.

\begin{tabular}{cccccc}
\hline No & Participant & Gender & Age & Type of School & $\begin{array}{c}\text { Experience in Teaching Pupils } \\
\text { with Dyslexia }\end{array}$ \\
\hline 1 & Teacher A & Female & 46 & Trust School & 10 years \\
2 & Teacher B & Male & 41 & National School & 12 years \\
3 & Teacher C & Female & 32 & National School & 3 years
\end{tabular}




\subsection{ESL Teachers' Experience with Pupils with Dyslexia}

A few themes have emerged from the interview as the teachers spoke about their experiences in teaching pupils with dyslexia. The first theme is on the reading and writing difficulties faced by the pupils with dyslexia. The second theme is their difficulties in relating to the personalities of the pupils with dyslexia.

\subsubsection{Reading and Writing Difficulties}

All three ESL teachers understood that pupils with dyslexia really struggle with language learning, what more in learning English as a second language. Their struggle in reading causes them to lag in their overall achievement in school. This is clearly seen as two participants reported that most pupils with dyslexia that they teach were either in the last class or in one or two cohorts lower than their age group:

"We take turn and we allocate the good and weak class[es] among us. Most [of] dyslexic students are in the last class..."

( Teacher A)

"For example, in the class that I'm teaching now, there is one pupil, he is 12 years old, but he is in Year Four class, the Year Four pupils are all 10 years old...but he is 12 ......"

( Teacher B)

This quote suggests that pupils with dyslexia are lagging behind due to their struggle with reading, resulting to them being placed in the weakest class or even together with the lower cohorts. As a result, the pupils would receive limited amount of ESL syllabus as opposed to what they should have been learning.

In addition, the participants agreed that pupils with dyslexia showed severe problems in English writing skills. For example, “....for the writing, they can copy...but to construct sentences, to make sentences, we need to help them....." (Teacher B) and “... writing is quite difficult for them..." (Teacher C). Reference (Reid, 2012) explains that writing ability is one area that is affected by dyslexia and teachers need to assist them in spelling, in sentence construction as well as in pupils' pencil grip. Incorrect way of holding and gripping a pencil may cause unnecessary tiredness and reduce pupils' motivation in learning to write and spell.

\subsubsection{Difficulties in Relating to Pupils' with Dyslexia Personality}

In terms of personality, two participants thought that pupils with dyslexia are either very talkative or very quiet based on their observation in their classrooms. This is mentioned by Teacher A that "Some of them are very chatty, one is very quiet. He will not say anything unless being asked by the teacher. He seems to be in his own world...”. Teacher C supported this finding by saying that "...they are more interested in listening and speaking skills activities...". Reference (Reid, 2012) suggests that teachers could capitalize on pupils' with dyslexia strengths in listening and speaking skills in order to motivate them in language learning. 
It is well-understood that young learners require more attention from the teacher in the classroom. The ESL teachers also thought that pupils with dyslexia need more attention from teachers compared to other pupils. This is clearly reflected from the quotation below:

"They always go to their special education teachers who teach in dyslexia class and tell about how other teachers talk to them in the class....hahaha....one boy told the dyslexia teacher that Teacher A did not scold him, Teacher A just talked to me nicely....hahaha...."

( Teacher $A$ )

"...they need attention more frequent compared to other pupils because they are active... they move a lot..."

( Teacher C)

Reference (Kormos, Csizér, \& Sarkadi, 2009; Nijakowska, 2016; Nijakowska, Jaroszewicz, \& Smith, 2013) state that pupils with dyslexia would show more progress in language learning if teachers have more positive attitudes towards their learning disabilities and pay special attention to them.

One interesting finding from the interview is that two participants mentioned that some of their pupils with dyslexia performed better than other typically developing pupils in English language test, including UPSR examination.

"... some of them are better in English performance. One of the dyslexic students got 70 marks...some normal students do not pass the test. I had 5 dyslexic students, all of them pass[ed] the UPSR exam...they were in the last class...".

( Teacher $A$ )

"some of these students are better than normal students... there is one pupil, he is 12 years old, but he is in Year Four class, the Year Four pupils are all 10 years old...but he is 12 ...he scored the highest mark for English in that class..."

(Teacher B)

This interview data reflect pupils' with dyslexia potential in language learning despite the learning difficulties they experience. It supports the notion that pupils with dyslexia can learn a second or a foreign language and can be successful in academic given the proper intervention and classroom instruction that suit their learning differences.

\subsection{Challenges Faced by ESL Teachers in Teaching Pupils with Dyslexia}

The researchers managed to identify some challenges faced by the ESL teachers in teaching pupils with dyslexia in mainstream classrooms. The mentioned challenges are big class size, limited special training related to dyslexia, difficulties in managing the emotion, behavior and motivation of pupils with dyslexia.

\subsubsection{Big Class Size}

All the three teachers stated that big size classes form a great challenge for them to teach pupils with dyslexia. The ESL teachers believed that pupils with dyslexia should be taught through one-to-one instruction or in small groups of four or less pupils. According to them, that is the best way to teach pupils who struggle 
to see the relationship between letters and sounds. To have pupils with dyslexia in the mainstream classroom is challenging for them because they knew those pupils need different techniques of teaching and learning as well as extra supporting materials.

"They want attention from the teachers. For Maths and Bahasa Melayu, they can go and learn with their dyslexia teachers in small groups, but why don't they have it for English language? We need to teach them in small groups...it is not easy to teach them in a class of 36 students."

\section{( Teacher $A$ )}

“...special education pupils and mainstream pupils are different...the number is too far different...maximum number in special education class is 8 , in mainstream 34...let's say...30 pupils in one class...there is one or two pupils with dyslexia in one class, we cannot give special attention to them although that is the only way we can help them."

( Teacher B)

"Remedial for English is done in the class... and there is no quality ample time to interact with the LINUS... as the BM and Maths are doing..."

( Teacher C)

\subsubsection{Limited Special Training Related to Dyslexia}

In addition, it was also difficult for the participants when there was no special training related to dyslexia provided for ESL teachers. This is mentioned by two participants; "No, there is none [course on dyslexia] so far..." (Teacher $A$ ) and " $I$ have never attended any course on dyslexia..." (Teacher $C$ ). This reflects the needs for training related to teaching method for pupils with dyslexia. However, Teacher B mentioned that there were courses provided for mainstream teachers such as Mathematics and Science teachers who are teaching pupils with specific learning disability:

“..for special education teachers, they have different courses for different teachers... according to their classes... we have many types of learning disabilities...not only dyslexia... so when they organized courses for different type of teaching method, other teachers will go...haaa...there are science, mathematics teachers... what they call....learning disabilities...hyperactive is another one...must always hold them...so different exposure on teaching method..."

(Teacher B)

\subsubsection{Managing Emotion, Behavior and Motivation of Pupils with Dyslexia}

Another challenge highlighted by the teachers is on managing the emotion, behavior and motivation of pupils with dyslexia. Each teacher found it difficult to balance between the need to give them high expectation as a way to motivate them, and the tactfulness in dealing with their sensitivity and low self-esteem.

"if we emphasize on a topic... when we pressure them a bit, he did not come to school...on the next day... he did not come to school. Because he cannot cope up...because although he is able, we want to help him so that he could achieve his 
true capability...ok..., when I asked for his homework, he kept quiet, straightaway kept quiet. He would not answer. If I keep on asking, he cried... There was a case, a boy, he looked physicallynormal, ok, ... when I asked a question or asked him to read, maybe he felt afraid if he answered wrongly, so he peed in his pants while standing..."

(Teacher B)

"...they do all the skills [language] but those dyslexic students who have other type of disabilities as well, they do not really participate..."

( Teacher $A$ )

These quotes reveal that the ESL teachers need more information on the effective ways in managing pupils with dyslexia's feeling, behavior and motivation. Reference (Nijakowska, Jaroszewicz, \& Smith, 2013; Burden, Burdett, Humphrey, \& Mullins, 2005; Csizér, Kormos, \& Sarkadi, 2010) explain that pupils with dyslexia mostly have low self-esteem and are anxious when it comes to learning language skills such as reading, spelling and writing. One of the things that teachers should do is to, as much as possible, avoid from giving written homework to pupils with dyslexia (Reid, 2012; Wennås Brante, 2013) since written homework may increase the dyslexics' anxiety about school and literacy learning.

Other challenges mentioned by the participants are lack of cooperation by parents of pupils with dyslexia, absenteeism and difficulties in training pupils with dyslexia to answer examination questions.

\subsection{Strategies in Teaching ESL to Pupils with Dyslexia}

From the interviews, several themes that come under strategies in teaching ESL to pupils with dyslexia have emerged which are drilling, differentiation, buddy system/peer coaching and a few other strategies.

\subsubsection{Drilling}

The interview data indicate that participant use various strategies in teaching pupils with dyslexia. Two participants stated drilling as one important strategy to teach reading and writing skills to pupils with dyslexia; for instance "I have to drill them a lot for them to be able to answer" (Teacher $A$ ) and "We would get the pupils... who are writing as similar as the dyslexia. So, we would get them drilled with writing correctly... especially the slant and so on..." (Teacher C). For this teacher, drilling is important because it allows for retention of information learned by the pupils with dyslexia.

\subsubsection{Differentiation}

On the other hand, Teacher A practices the use of differentiation in activities as a strategy to cater to the needs of pupils with dyslexia.

"I use the same teaching materials to explain about the lessons for all students. The differentiation is done during the activities such as group work".

( Teacher $A$ )

Differentiation is the main concept applied in all Trust Schools (Sekolah 
Amanah) in Malaysia, which focuses on the uniqueness of each individual learners. Differentiation is done in 4 aspects; learning styles, materials, activities and learning product, to cater to every pupil's learning needs. Through this strategy, Teacher A believes that the needs of her pupils with dyslexia could be met as more personal attention could be provided.

\subsubsection{Buddy System/Peer Coaching}

On the other hand, Teacher B prefers to use the buddy system or peer coaching to teach ESL to pupils with dyslexia.

"I cannot afford to sit beside them,... have to use peer teaching method.... kids like to help this kind of pupils [dyslexics]... we choose one or two, so that they could become the mentor without him knowing he has got a mentor...so, he would be happy to sit beside and learn and help...really works...really works....tasks completed, even though he cannot do on his own, but with his friend's help, he can finish..."

(Teacher B)

\subsubsection{Other Strategies}

Teacher B also stresses on the importance of the teacher to sit beside pupils with dyslexia during lessons to provide special attention and personal guidance:

"dyslexia is really a special case....so we sit besides him... we must win his heart first... win him or her heart...so he is comfortable with us, right? With me, he can follow my instruction... he can do..."

Describing about her strategy, Teacher $\mathrm{C}$ thinks that asking pupils with dyslexia to practise writing using triple lines exercise book is helpful. In addition, she always corrects her pupils' mistakes at the first instance of the mistake so that they would practise what is right from the very beginning. She also mentioned about using songs in teaching ESL and focusing on the mechanics of writing such as parallel writing.

Reflecting on all the strategies shared by the teachers of pupils with dyslexia, there is nothing new or unique about them. One-to-one or small group teaching, drilling, personalized teaching or differentiation techniques, peer coaching, and using songs in teaching ESL are all common practices in any ESL classrooms. None of the ESL teachers mention about multisensory techniques or phonics as the teaching strategies used to help pupils with dyslexia, when in fact, these two techniques have been proven by many previous studies (Subramaniam \& Che Mat, 2013; Nijakowska, 2016) as effective methods in helping pupils with dyslexia to learn reading, spelling and writing.

\section{Conclusion}

In this paper, we investigated three ESL teachers' experiences in teaching pupils with dyslexia in primary school mainstream settings by means of interview. Our data reveal that the teachers generally find it challenging to cater to the ESL learning needs of pupils with dyslexia. ESL teachers explained that without proper training, they could hardly provide effective teaching and learning to pu- 
pils with special educational needs. A complementary finding of our research is that some pupils with dyslexia performed better in English language achievement tests compared to the typically developing pupils. Also, these pupils with special needs showed less behavioral problems as compared to the other pupils. Our findings show that although the teachers gave special attention to pupils with dyslexia, they have not really ventured into teaching methods involving multisensory methods or phonics. It is highly important that ESL teachers who are teaching pupils with dyslexia in mainstream classrooms are provided with specific skills in teaching, managing and motivating this group of pupils.

It is recommended for future studies to explore the perspectives of other ESL educators by interviewing secondary school teachers as well as lecturers who are teaching students with dyslexia in Malaysia. This should be done in order to accommodate their language learning needs specific to their level of education. It is also essential to talk to students identified as dyslexic besides interviewing their parents to explore on their experience in learning ESL. Their insights would guide teachers and educators in giving the best language learning experience for them besides helping them to perform in ESL tests and examination. Finally, the most important issue is how to best identify pupils with dyslexia in order to assist them in learning. In order to be able to do that, teachers must be able to recognize and identify pupils with dyslexia in their classrooms. Thus, it is high time to develop a validated instrument to identify dyslexia among Malaysian pupils who learn English as a second language. This study has implications on the availability of a standardized local instrument for identifying dyslexia and enhancement of knowledge on dyslexia among teachers.

\section{Conflicts of Interest}

The authors declare no conflicts of interest regarding the publication of this paper.

\section{References}

Balakrishnan, B., Chong, H. B., Idris, M. Z., Othman, A. N., Wong, M. F., Nor, M., \& Azman, A. (2015). Improving the English Literacy Skills of Malaysian Dyslexic Children: The Case of Culturally Responsive Mobile Multimedia Tool. Geografia Online, 11, 49-59.

Bell, S., Mcphillips, T., \& Doveston, M. (2011). How Do Teachers in Ireland and England Conceptualise Dyslexia? Journal of Research in Reading, 34, 171-192.

https://doi.org/10.1111/j.1467-9817.2009.01419.x

Bellocchi, S., Tobia, V., \& Bonifacci, P. (2017). Predictors of Reading and Comprehension Abilities in Bilingual and Monolingual Children: A Longitudinal Study on a Transparent Language. Reading and Writing, 30, 1311-1334.

https://doi.org/10.1007/s11145-017-9725-5

Burden, R., Burdett, J., Humphrey, N., \& Mullins, P. (2005). Factors Associated with Successful Learning in Pupils with Dyslexia: A Motivational Analysis. British Journal of Special Education, 32, 100-104.

Csizér, Kata, Kormos, J., \& Sarkadi, Á. (2010). The Dynamics of Language Learning Atti- 
tudes and Motivation: Lessons from an Interview Study of Dyslexic Language Learners. Modern Language Journal, 94, 470-487. https://doi.org/10.1111/j.1540-4781.2010.01054.x

Duff, F. J., Hulme, C., Grainger, K., Hardwick, S. J., Miles, J. N. V., \& Snowling, M. J. (2014). Reading and Language Intervention for Children at Risk of Dyslexia: A Randomised Controlled Trial. Journal of Child Psychology and Psychiatry and Allied Disciplines, 55, 1234-1243. https://doi.org/10.1111/jcpp.12257

Farukh, A., \& Vulchanova, M. (2016). L1, Quantity of Exposure to L2 and Reading Disability as Factors in L2 Oral Comprehension and Production Skills. Learning and Individual Differences, 50, 221-233. https://doi.org/10.1016/j.lindif.2016.07.013

Instrumen Senarai Semak Disleksia BM (2014). Malaysian Ministry of Education. Malaysia.

International Dyslexia Association (2002). https://dyslexiaida.org/definition-of-dyslexia/

Kalindi, S. C., McBride, C., Tong, X., Wong, N. L. Y., Chung, K. H. K., \& Lee, C. Y. (2015). Beyond Phonological and Morphological Processing: Pure Copying as a Marker of Dyslexia in Chinese but Not Poor Reading of English. Annals of Dyslexia, 65, 53-68. https://doi.org/10.1007/s11881-015-0097-8

Kormos, J., Csizér, K., \& Sarkadi, Á. (2009). The Language Learning Experiences of Students with Dyslexia: Lessons from an Interview Study. Innovation in Language Learning and Teaching, 3, 115-130. https://doi.org/10.1080/17501220802638306

Lee, L. W. (2008). Development and Validation of a Reading-Related Assessment Battery in Malay for the Purpose of Dyslexia Assessment. 37-57.

Lee, L. W., Ali, M. M., \& Salleh, N. (2008). Pembinaan dan Pengesahan Ujian Membaca Perkataan dan Ujian Mengeja untuk Tujuan Mengenalpasti Disleksia: Satu Kajian Rintis. Jurnal Pendidik Dan Pendidikan, 23, 151-162.

Liyana, A. A., Hanapi, N. F., Zakaria, K. B., Binti, L., Afip, A., Fatihah, N., \& Insaniah, P. (2013). Persepsi dan Pengalaman Guru Pendidikan Khas dalam Menghadapi Permasalahan Disleksia dalam Kemahiran Literasi. In Proceedings of Seminar Sains Kemanusiaan OKU Peringkat Kebangsaan (pp. 1-14). Kelantan: UMK Press.

Lockiewicz, M., \& Jaskulska, M. (2016). Difficulties of Polish Students with Dyslexia in Reading and Spelling in English as L2. Learning and Individual Differences, 51, 256-264. https://doi.org/10.1016/j.lindif.2016.08.037

Nijakowska, J. (2016). Grasping Dyslexia : Bridging the Gap between Research and Practice. In Proceedings of 21st International Symposium on Theoretical and Applied Linguistics (pp. 43-58). Thessaloniki: Aristotle University of Thessaloniki Press.

Nijakowska, J., Jaroszewicz, B., \& Smith, A. M. (2013). Dyslexia for Teachers of English as a Foreign Language. Trainee's Booklet.

Ogunsola, B. A. (2018). Teachers' Qualifications and Dyslexia Identification in Primary Schools in Oyo State, Nigeria. Africa Education Review, 6627, 1-31.

Pin, P. H. (2013). Management of Special Education Teacher to Upgrade the Mastering of Reading Skills of Dyslexia Pupils. International Journal of Science and Research (IJSR), 2, $248-251$.

Ramasamy, R. (2008). Masalah disleksia dalam kalangan Murid-Murid pemulihan di sekolah rendah, Pulau Pinang. Master Thesis, Penang: Universiti Sains Malaysia.

Reid, G. (2012). Dyslexia and Inclusion: Classroom Approaches for Assessment, Teaching and Learning. ¡Abingdon-on-Thames: Routledge.

Reraki, M. (2014). Classroom-Based Interventions for Achieving "Dyslexia-Friendly" Classrooms in Language Education: Pupils' and Teachers' Perspectives. International 
Conference: The Future of Education, 1-4.

https://www.research.manchester.ac.uk/portal/files/54579593/FULL_TEXT.PDF

Sotiropoulos, A., \& Hanley, J. R. (2017). Developmental Surface and Phonological Dyslexia in Both Greek and English. Cognition, 168, 205-216. https://doi.org/10.1016/j.cognition.2017.06.024

Subramaniam, V., \& Che Mat, N. H. (2013). The Mastery of the 3M among Dyslexia Children based on the Revised Dyslexia List Instrument Screening Test. GLobal Journal of Human Social Science Linguistics and Education, 13, 41-47.

Wennås Brante, E. (2013). “I Don’t Know What It Is to Be Able to Read": How Students with Dyslexia Experience Their Reading Impairment. Support for Learning, 28, 79-86. https://doi.org/10.1111/1467-9604.12022

Worthy, J., Dejulio, S., Svrcek, N., Villarreal, D. A., Derbyshire, C., Leekeenan, K., Salmero, C. et al. (2016). Teachers' Understandings, Perspectives, and Experiences of Dyslexia. Literacy Research: Theory, Method, and Practice, 65, 436-453. 